\section{Pulmonal hypertensjon i frakkelommen}

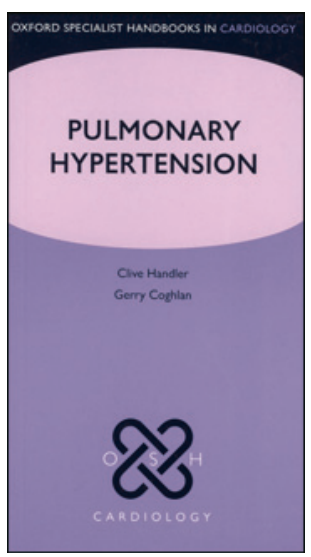

Clive Handler, Gerry Coghlan Pulmonary hypertension

237 s, tab, ill. Oxford: Oxford University Press, 2012. Pris GBP 35

ISBN 978-0-19-957256-4

Klassikeren Oxford handbook of clinical medicine har vært en velkjent følgesvenn i frakkelommen til unge leger i landets akuttmottak gjennom mange år. Kliniske håndbøker i lommeformat må kunne sies å ha vært en stor suksess, når det bare hos Oxford University Press finnes mer enn 200 slike utgivelser.

Med sine $10 \times 18 \mathrm{~cm}$ og 237 sider er Pulmonary hypertension én av 16 håndbøker i serien Oxford specialist handbooks in cardiology, som samlet dekker så godt som hele det kardiologiske fagfeltet. Målgruppen er klinikere som er involvert i diagnostikk og behandling av pasienter med pulmonal hypertensjon, både kardiologer, lungeleger, revmatologer, gastroenterologer, infeksjonsmedisinere og hematologer.

Boken er meget lettlest og systematisk inndelt i ni hovedkapitler med respektive underkapitler. Forfatterne tar for seg både historikk, definisjoner, klassifisering, patofysiologi, genetikk, epidemiologi, diagnostikk og behandling. Tilstander assosiert med pulmonal hypertensjon er grundig omtalt i egne kapitler.

Teksten er stort sett presentert punktvis og kortfattet, som seg hør og bør for en håndbok, med lettfattelige tabeller. Figurene er derimot av meget varierende kvalitet, fra uleselige svart-hvitt-bilder til flotte, illustrative fargebilder. Det er referanseliste og forslag til ytterligere litteratur på slutten av de fleste kapitlene. Den kardiologisk interesserte legen vil spesielt like kapitlene som omhandler ekkokardiografisk vurdering av høyre hjertehalvdel og høyresidig hjertekateterisering.

En styrke er at forfatterne omtaler de gjeldende europeiske retningslinjene for diagnostikk og behandling av pulmonal hypertensjon, utgitt av European Society of Cardiology i 2009. Svakheten er selvfølgelig at slike bøker fort blir utdaterte.

Jeg kan anbefale boken på det sterkeste til leger i spesialisering i kardiologi som ønsker en lettfattelig innføring i et vanskelig felt, i tillegg til kardiologer og andre klinikere som diagnostiserer og behandler pasienter med pulmonal hypertensjon. Derimot bør boken neppe benyttes til å fylle opp allerede overfylte frakkelommer hos vaktgående leger på generelle indremedisinske avdelinger.

Jørgen A. Gravning

Akershus universitetssykehus

\section{Helse i slaveri og frihet}

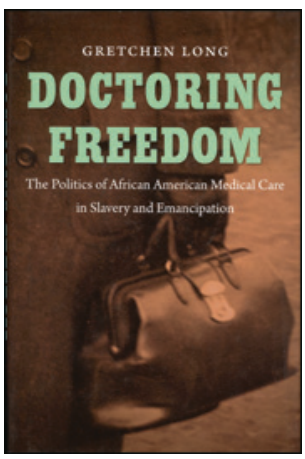

Gretchen Long

\section{Doctoring freedom}

The politics of African American medical care in slavery and emancipation. 234. Chapel Hill, NC: The University of North Carolina Press, 2012. Pris USD 38

ISBN 978-0-8078-3583-8

De amerikanske sørstatenes vei fra et slavesamfunn til et samfunn der alle innbyggere er frie, har vært lang og vanskelig. I denne boken beskriver Gretchen Long den afroamerikanske befolkningens helsetilbud - som slaver før borgerkrigen, som krigskontrabande og soldater under borgerkrigen, og som frie amerikanske borgere etter borgerkrigen.

Gjennom beskrivelsen av den afroamerikanske helsepolitikken illustrerer hun at slavesamfunnet egentlig var to parallelle samfunn. I alle aspekter av samfunnet hadde slaven og den frie innbyggeren forskjellige roller. Ideen om at slavene hadde andre helsebehov og var utsatt for andre sykdommer enn frie mennesker var en del av forskjellstenkningen som var nødvendig for at slavesamfunn skulle bestå.

Boken er kronologisk bygd opp, og Long starter med å beskrive sørstatenes helsepolitikk overfor slavene før borgerkrigen.

Paradoksalt nok hadde mange afroamerikanere lettere tilgang på helsetjenester som slaver, enn som frie borgere etter borgerkrigen, men det var avhengig av eieren. Slavene representerte verdifull arbeidskraft. Det var derfor i slaveeierens interesse at gravide slaver fikk fødselshjelp for å sikre vellykket avkom og minst mulig skade på kvinnen. Slaveeiere sørget også for helsehjelp til voksne slaver slik at de var friske og arbeidsføre. Eldre slaver som ikke lenger kunne arbeide, fikk sjelden tilgang til helsetjenester i det hele tatt.

Under borgerkrigen betraktet hæren i nordstatene de frigjorte slavene som krigskontrabande, og slavene ble konfiskert fra eierne og internert i leire. Mange mannlige slaver vervet seg til unionshæren. Der fikk de tidligere slavene for første gang erfare den frie mannens pasientrolle. Kvinnene og barna i interneringsleirene ble overlatt til seg selv og hadde ingen rettigheter til medisinsk behandling.

Etter borgerkrigen var afroamerikanerne ikke lenger slaver, og ingen slaveeiere tok ansvar for deres helse. De måtte lære seg å gjøre det selv, men det var ikke lett når mange var arbeidsløse, og de bare hadde erfaring med slaverollen. Amerikanske myndigheter organiserte afroamerikanske foreninger der det ble inndrevet en skatt for å betale for helsetjenester. Foreningene fungerte som en kollektiv helseforsikringsordning. Helsetjenestene ble stort sett kjøpt fra hvite leger. Etter hvert dannet afroamerikanerne egne utdanningsinstitusjoner for afroamerikanske leger, men utdanningen var mangelfull, og tjenestene holdt ikke samme standard som de tjenestene de hvite fikk.

Long gir utallige eksempler, og det er en fyldig referanseliste. Boken fremstår som en vitenskapelig avhandling og retter seg mot et akademisk publikum. Den gir imidlertid et verdifullt innblikk $i$ helsepolitikkens betydning i afroamerikanernes kamp for like borgerrettigheter.

Erik Fosse

Intervensjonssenteret

Oslo universitetssykehus 